\title{
Die behandeling van die funksie dekodering in verskillende tipes woordeboeke*
}

\author{
Anna Nel Otto, Departement Tale en Letterkunde, Nelson Mandela \\ Universiteit, Port Elizabeth, Suid-Afrika (anna.otto@mandela.ac.za) \\ en \\ Jadé Blume, Departement Tale en Letterkunde, Nelson Mandela Unversiteit, \\ Port Elizabeth, Suid-Afrika (jade.blume@mandela.ac.za)
}

Opsomming: Woordeboeke word veral geraadpleeg ter wille van die funksie dekodering. Hierdie artikel verskaf 'n sistematiese beskrywing van die invloed wat die funksie dekodering op die woordeboekstrukture en datatipes in verskillende woordeboektipes het. Tydens hierdie bespreking word veral aandag gegee aan strukture wat in sowel gedrukte as aanlyn woordeboeke voorkom. Alhoewel die belangrikste datatipe vir dekodering betekenisverklarings/vertalings in meertalige woordeboeke is, fokus hierdie artikel veral op die rol van datatipes soos uitspraakleiding, kollokasies, etikette, voorbeelde en etimologiese leiding. In gedrukte woordeboeke is daar ' $n$ groot ooreenkoms ten opsigte van raamstruktuur (minstens sentrale woordelys en gebruikersleiding), dataverspreidingstruktuur en toegangstruktuur, terwyl verskille veral op die vlak van die makrostruktuur (meer of minder lemmas, verskillende ordenings) en mikrostruktuur (aanduidertipes en hoeveelheid data ten opsigte hiervan) voorkom.

Sleutelwoorde: DEKODERING, WOORDEBOEKTIPES, WOORDEBOEKSTRUKTUUR, WOORDEBOEKFUNKSIE, OMVATTENDE WOORDEBOEK, STANDAARDWOORDEBOEK, BEPERKTE WOORDEBOEK, AANLEERDERWOORDEBOEK, WOORDEBOEK VIR SPESIALE DOELEINDES, TWEETALIGE WOORDEBOEK

\begin{abstract}
The Treatment of the Function Decoding in Different Types of Dictionaries. Dictionaries are especially consulted for the function of decoding. This article provides a systematic description of the influence that this function has on the dictionary structures and data types in different types of dictionaries. In this discussion attention is paid to structures which appear in both printed and online dictionaries. Although the most important data type for decoding is meaning explanations/translation equivalents in multilingual dictionaries, this article focuses especially on the role of data types such as pronunciation guidance, collocations, labels, illustrations and etymological data. In printed dictionaries there is a resemblance in terms of frame structures (at least a lemma list and usage guidance), data distribution structure and access structure, while differences are more on the level of the macrostructure (quantity of lemmata and different ordering) and microstructure (indicator types and quantity of data).
\end{abstract}

* Hierdie artikel is ' $n$ verwerkte weergawe van 'n ongepubliseerde M.A.-verhandeling, Blume 2017. 
Keywords: DECODING, DICTIONARY TYPES, DICTIONARY STRUCTURE, DICTIONARY FUNCTION, COMPREHENSIVE DICTIONARY, STANDARD DICTIONARY, RESTRICTED DICTIONARY, LEARNER'S DICTIONARY, DICTIONARY FOR SPECIAL PURPOSES, BILINGUAL DICTIONARY

\section{Inleiding}

Een van die belangrikste funksies in woordeboeke is dekodering. Die woord dekodering moet hier verstaan word as die verkryging van begrip wanneer ' $n$ gebruiker byvoorbeeld 'n onbekende woord naslaan en dit probeer verstaan (Svensén 2009: 12). Dit word in die eerste instansie vergestalt in definisies/ betekenisverklarings in woordeboekkonteks. Morris (1985: 6) verwoord dit indirek soos volg: "The soul of a dictionary, however, is the quality of its definitions."

Die doel van hierdie artikel is om 'n sistematiese beskrywing te verskaf van die invloed wat die funksie dekodering op die woordeboekstrukture en datatipes in verskillende woordeboektipes het. Aangesien hierdie doel verband hou met die daarstel van beter woordeboeke, val dit binne die leksikografie as dissipline. Binne die leksikografie is daar vir 'n lang tydperk gefokus op tradisie en woordeboekinhoud. 'n Tipiese tweetalige woordeboek het byvoorbeeld hoofsaaklik gefokus op die verskaffing van vertaalekwivalente. Mettertyd het leksikograwe meer en meer bewus geword van die feit dat teikengebruikers woordeboeke vir verskillende funksies en in verskillende situasies gebruik. Sommige gebruikers stel slegs in betekenisverklarings (vir dekodering) belang, terwyl ander graag woorde korrek binne konteks wil gebruik (vir produksie). Die rasionaal vir hierdie artikel is om die leemte te vul ten opsigte van 'n sistematiese beskrywing van die invloed wat die funksie dekodering op die woordeboekstrukture en datatipes in verskillende woordeboeke het. Terwyl die belangrikste datatipe vir dekodering betekenisverklarings/vertaalekwivalente in meertalige woordeboeke is en reeds redelik uitvoerig in die literatuur bespreek is, fokus hierdie artikel veral op die rol van datatipes soos uitspraakleiding, kollokasies, etikette, voorbeelde, illustrasies en etimologiese leiding.

Dekodering is maar een van verskeie funksies wat in woordeboeke voorkom. Binne die metaleksikografie is die verskillende funksies reeds geïdentifiseer en die aard daarvan aangetoon, veral deur aanhangers van die funksieteorie (vergelyk onder andere Bergenholtz en Tarp 2003), maar 'n sistematiese beskrywing van die verhouding tussen 'n bepaalde funksie, woordeboekstrukture en datatipes in verskillende woordeboektipes is eers in 2017 voltooi in die vorm van 'n verhandeling, wat fokus op die funksies dekodering, produksie en vertaling (Blume 2017).

In die leksikografie word dit wyd aanvaar dat woordeboeke gespesifiseerde teikengroepe se behoeftes en naslaanvaardighede in ag moet neem. Dit het implikasies vir die funksie(s) wat die woordeboek moet hê en die daarmee gepaardgaande strukture, databehandeling en woordeboektipe. In hierdie ver- 
band wys Gouws (2018: 180) op die voorkeur van Generasie Z (persone wat na 2000 gebore is) om al hulle data van een bron te verkry, veral die internet. Aanpassings by die digitale omgewing is dus belangrik vir metaleksikograwe (Gouws 2018: 180). Individue binne ander generasies het nie noodwendig dieselfde behoeftes as Generasie Z nie, gevolglik word daar saamgestem met die siening van Gouws (2018: 181) dat aandag gegee moet word aan strukture wat in sowel gedrukte as aanlyn woordeboeke voorkom, maar bepaalde aanpassings in aanlyn woordeboeke vereis, en ook aan die strukture wat slegs in een van die twee tipes voorkom. Dziemianko (2017) wys ook in hierdie verband op die feit dat daar nog nie statisties beduidende bewyse is dat die vorm (gedruk teenoor elektronies) 'n deurslaggewende rol speel by dekodering en produksie nie, maar dat veral vir aanleerders die elektroniese formaat beter blyk te wees vir kitshulp om taalprobleme op te los en vir retensie (Dziemianko 2017: 349).

Die werkswyse is om aan die hand van 'n literatuurstudie en illustrasievoorbeelde te peil hoe die strukture en data-inhoude van woordeboektipes soos omvattende woordeboeke, standaardwoordeboeke, tweetalige woordeboeke, beperkte woordeboeke en woordeboeke vir spesiale doeleindes verpak behoort te wees ten einde suksesvolle dekodering in die hand te werk.

\section{Omvattende woordeboeke}

Omvattende woordeboeke se primêre funksie is om die taal so volledig moontlik te dokumenteer. Naas dekodering is die kennisgerigte funksie ook ter sake in omvattende woordeboeke. Die kennisgerigte funksie is relevant met betrekking tot die raamstruktuur in gedrukte woordeboeke, terwyl daar veral in ' $n$ aanlyn woordeboek na eksterne bronne, byvoorbeeld die internet, verwys kan word, en in hierdie verband is die datatrekkingstruktuur van belang, waarvolgens gebruikers vanaf enige soeksone data aan die internet kan onttrek (Gouws 2018: 192).

Wat data-inhoud betref, dui Gouws (2017: 442) aan dat daar geen beperking is op die hoeveelheid lemmas by ' $n$ omvattende woordeboek nie, en Tarp (2008) beklemtoon die relevansie van ongereelde fleksievorme, idiome en spreekwoorde as lemmata wat verklaar behoort te word.

\subsection{Die raamstruktuur}

Die sentrale woordelys is die belangrikste, verpligtende element in die gedrukte woordeboek (Gouws 2017: 447). Dit moet alfabeties georden word en sluit in enige data wat relevant vir die funksie dekodering is. Die voorteks behoort ook 'n gebruikersleiding te bevat (Gouws 2017: 447).

Die gebruikersleiding moet duidelik aandui hoe sekere datatipes opgespoor kan word. In hierdie verband dui Svensén (2009: 382) die volgende vereistes aan: Daar moet ' $n$ volledige verduideliking van die makro-, mikro- en mediostruktuur van die woordeboek wees, sowel as hoe die verskillende data- 
tipes aangebied word. Die manier hoe struktuurmerkers werk, moet aangedui word, en ' $n$ lys redaksionele afkortings met hulle volvorme is nodig. In elektroniese woordeboeke is artikels noodsaaklik en daarnaas ook gebruikersleiding deur middel van skermskote ten einde data optimaal te benut. Dit kan aangevul word deur 'n rubriek gereelde vrae of 'n begeleide toer, wat die gebruikers deur middel van 'n voorbeeldsoektog touwys maak. Laastens is daar ook die moontlikheid om tydens probleemsituasies 'n leermeester op interaktiewe wyse te raadpleeg (Kemmer 2010: 6).

Enige bykomende data wat belangrik is vir die funksie dekodering, soos ensiklopediese en/of kulturele data, kan verder in die agterteks in gedrukte woordeboeke verskyn, indien dit nie reeds in die artikels opgeneem is nie. Dit is wel waarskynlik dat data soos geografiese name en mitologiese figure in die sentrale teks betrek word omdat omvattende woordeboeke gewoonlik 'n meerdelige produk is, waar een of meer letters by elke deel betrek word en hierdie dele op verskillende tye verskyn (Gouws 2017: 442). In elektroniese woordeboeke kan hierdie data in tekste rondom die sentrale teks verskyn, aangesien dit nie lineêr georden is nie.

\subsection{Die dataverspreidingstruktuur}

Die teikengebruiker moet die nodige inligting vir dekodering maklik kan onttrek, hoofsaaklik uit die woordeboek se sentrale teks. Relevante bykomende data kan verder in die voor- en/of agterteks verskyn. In die WAT (deel XII) word byvoorbeeld die volgende aspekte in die voorteks hanteer: inleiding, gebruiksleiding en redaksionele afkortings. Die gebruiksleidingafdeling dui vir die teikengebruikers aan watter tipes data in die WAT verskyn en waar in die woordeboekartikels die data opgeneem word. Hierdie toeligting help die gebruiker om lemmas en sublemmas vinniger op te spoor en beter te begryp. Sinonieme en kruisverwysings kan byvoorbeeld begrip bevestig indien die betekenisverklaring nie volkome duidelik is nie. In die toeligting word onder andere rostrum as sinoniem van podium aangedui. Verder word daar aangedui dat kruisverwysings deur "Vgl." ingelei word. Onder pikbroek staan byvoorbeeld: Vgl. MATROOS, SEEROB. Die gebruiker kan ook kennis neem van die feit dat vorme wat soms met die lemma verwar word, deur "onderskei van" aangedui word en dat "OPM." vir verdere verduidelikings gebruik word.

\subsection{Die makrostruktuur}

Die opname van ensiklopediese en kulturele data in 'n omvattende woordeboek sal die gebruiker help om 'n betrokke woord in die korrekte konteks te verstaan. Klosa (2016: 523) noem dat kulturele data in die betekenisverklarings, voorbeelde en kollokasies opgeneem kan word. Die aanbevelings vir die opname en bewerking van lemmas in 'n omvattende woordeboek is soos volg, ondersteun deur data uit Svensén (2009: 368-378), Gouws (2017: 442-444), Béjoint (2016: 18), 
Klosa (2016: 524-530) en Kemmer (2010: 8):

- Soveel lemmas as moontlik moet opgeneem word.

- Die lemmakeuse moet uit die standaardvariëteit geneem word, asook uit ander variëteite. Etikette moet gebruik word waar daar ' $n$ afwyking van die standaardtaal is.

- In gedrukte woordeboeke is die ordening gewoonlik alfabeties.

- In elektroniese woordeboeke kan naas die alfabetiese lemmalyste, wat voorafgaande en daaropvolgende lemmas kan aandui, ook die volgende verskaf word: óf (soos in tesourusse) parallelle lemmalyste wat volgens woordvelde georganiseer is, óf 'n lemmalys wat volgens frekwensie gebaseer is (Kemmer 2010: 8).

\subsection{Die mikrostruktuur}

Die artikels, met hulle geordende inskrywings, vorm die mikrostruktuur (Gouws 2017: 452). In ware aanlyn woordeboeke, wat nie net 'n duplisering is van die data in 'n gedrukte woordeboek nie, is daar nie 'n soortgelyke ordening as in 'n gedrukte woordeboek nie.

Die invloed wat die funksie dekodering op die mikrostruktuur in gedrukte omvattende woordeboeke het, word vervolgens bespreek.

\subsubsection{Aanduiders en struktuurmerkers}

Aanduiders (data) en struktuurmerkers is albei ter wille van dekodering nuttig in alle tipes gedrukte woordeboeke. Aanduiders sluit in onder andere woordsoorte, meervoudsvorme en verkleiningsvorme (Gouws 2003: 35 en Gouws 2017: 452). Tarp (2008: 77) noem dat onder andere woordsoorte, woordkombinasies en fleksievorme datatipes is wat vir dekodering opgeneem behoort te word.

Struktuurmerkers help die gebruiker om so vinnig en so maklik moontlik by ' $n$ spesifieke item uit te kom (Gouws 2017: 453). Tipografiese struktuurmerkers sluit in leksikale items wat in vetdruk, kursief, ensovoorts aangedui is, terwyl nietipografiese struktuurmerkers gewoonlik simbole is, byvoorbeeld ' $n$ klein blokkie of omgekeerde driehoek, wat die gebruiker help om vinnig by ' $n$ item uit te kom. Ronde hakies word byvoorbeeld onder andere as nietipologiese struktuurmerker in die WAT XII gebruik om betekenis te presiseer, soos byvoorbeeld in die volgende geval: parlement... $\mathbf{b}$ spesifieke samestelling van 'n parlement (PARLEMENT $1 \mathrm{a}$ i).

\subsubsection{Uitspraakleiding}

In gevalle waar 'n betrokke woord verskillende uitsprake het, behoort die gebruiker uitspraakleiding te kry om tussen die twee betekenisse te kan onderskei, soos in die WAT X by oorweeg. 


\subsubsection{Kollokasies}

Kollokasies is woorde wat dikwels saam gebruik word en nie 'n vrye verbinding of vaste uitdrukking is nie (Gouws 1989: 97; Bentivogli en Pianta 2002: 786). Volgens Tarp (2008: 254) moet kollokasies nie in 'n woordeboek vir die funksie dekodering opgeneem word nie omdat die aparte dele van die kollokasie vir teksbegrip opgesoek kan word. Otto (2013: 189) en Howarth (1998: 101) dui wel die belang van kollokasies vir onder andere moedertaalsprekers aan, aangesien die praktyk bewys lewer dat moedertaalsprekers probleme ondervind met die korrekte begrip en gebruik van kollokasies. Die gebrekkige begrip van 'n bepaalde kollokator kan tot kontaminasievorme lei, soos byvoorbeeld in die geval van nood oorbrug, waar die bedoeling nood verlig is en dit verwar word met ' $n$ probleem oorbrug.

\subsubsection{Etikette}

Volgens Gouws (1988: 4) verwys die term etiket "na daardie inskrywing(s) in 'n woordeboekartikel wat as merkers optree om die lemma of 'n ander inskrywing in die artikel se beperkings ten opsigte van byvoorbeeld stylaard, gebruiksfeer en geografiese voorkoms aan te dui". In die WAT XI word byvoorbeeld by opstopper deur middel van die etiket (boks) onder andere onderskei tussen 'n harde vuishou deur enigiemand en ' $n$ vuishou deur ' $n$ bokser as ' $n$ besondere tipe vuishou.

\subsubsection{Illustrasies}

Ilson (1987: 193) dui, met betrekking tot gedrukte woordeboeke, aan dat die begrip "illustrasies" as dekkingsterm dien vir: tabelle, diagramme sowel as prente, met ander woorde vir alle vorme van nielineêre aanbieding waarin die vorm van die voorstelling die items of hulle verbande met mekaar voorstel.

Hoewel dit nuttig kan wees vir dekodering, moet illustrasies in die lig van die hoë onkoste daarvan spaarsamig in gedrukte woordeboeke gebruik word. In elektroniese woordeboeke voeg illustrasies waarde toe, veral ten opsigte van dekodering deur middel van teks, prente, film, geluide, animasie en simulasie (Sager 2000: 588).

\subsection{Die toegangstruktuur}

Die eksterne toegangstruktuur, wat die soekroete is wat die gebruiker volg om by 'n bepaalde datatipe uit te kom, sal die omslag/naam van die woordeboek, die gebruikersleiding en loopkoppe (in gedrukte woordeboeke) wees.

Bothma (2011: 82-83) dui aan dat die tipiese soekroete in 'n e-woordeboek presies gee waarvoor die gebruiker vra en dat 'n gevorderde soekroete ook 
moontlik is. Skakels kan gebruikers help om vinnig tussen kruisverwysings rond te beweeg om data vir dekodering op te spoor, soos in die volgende afdeling aangetoon sal word. Die bruikbaarheidsbenadering is hier van belang (vergelyk Du Plessis 2017: 2).

\subsection{Die mediostruktuur}

Die mediostruktuur verwys die gebruiker na verwante data deur die gebruiker tussen verskillende dele van 'n woordeboek te neem (Svensén 2009: 388). Volgens Gouws (2018: 186) kan die gebruiker ook na verwante data in 'n ander woordeboek in 'n woordeboekportaal of eksterne kruisverwysingsadresse verwys word. Dit kan op enige plek in die woordeboekartikel voorkom (Bogaards 2013: 25).

Die mediostruktuur het verskillende funksies, waaronder veral ruimtebesparing in gedrukte woordeboeke, maar dit kan terselfdertyd semantiese verbande aantoon. In die WAT XII word byvoorbeeld soms kruisverwysings na sinonieme aangebied. By padren word na padwedren verwys en die definisie verskyn onder padwedren. 'n Wisselvormverwysing het die aanloop "Sien". By paarsgewyse, byvoorbeeld, word die kruisverwysing aangedui as: Sien PAARSGEWYS..." Die definisie verskyn by paarsgewys. Daar kan ook kruisverwysings na formele antonieme en verwante of maklik verwarbare leksikale items wees. Antonieme word in die WAT XII deur "teenoor" aangedui, terwyl vorme wat verwar kan word, ingelei word deur "onderskei van". Die antonimiese verwysing by palingenese 3 , byvoorbeeld, word aangedui as "onderskei van anateksis". Dit is veral laasgenoemde vorme wat ter wille van dekodering duidelik van mekaar onderskei moet word.

In e-woordeboeke word die mediostruktuur vergestalt in skakels, wat die gebruiker help om die datatipe waarna verwys word, maklik en vinnig op te spoor (Oppentocht en Schutz 2003: 218). Ten einde dit te kan doen, moet die woordeboekgebruikers weet op watter vlak hulle hulle bevind indien die betrokke omvattende woordeboek ingebed is in 'n woordeboekportaal. Daar moet dus 'n soekenjin wees wat sentraal op die tuisblad georiënteer is en wat aandui hoe daar op elke woordeboekvlak gekom kan word (Klosa, Lemnitzer en Neumann 2008:10).

\section{Standaardwoordeboeke}

Die meeste gedrukte standaardwoordeboeke het meer as een funksie omdat hulle dikwels help met dekodering en produksie. Die Verklarende Afrikaanse Woordeboek (VAW) is primêr op spellingleiding en begrip gerig, maar verskaf wel soms frases, hoewel nie naastenby soveel, en veral volsinne, soos die Handwoordeboek van die Afrikaanse Taal (HAT6) nie. Terwyl op die omslag van die HAT6 aangedui word dat daar meer as 80000 voorbeelde van tipiese taalgebruik is, word in die voorwoord van die VAW gemeld dat die VAW veral op 
die trefwoord en sy gepaardgaande grammatikale inligting fokus en dat daar 8000 frases is.

Aangesien gedrukte standaardwoordeboeke duur is, sal gebruikers moontlik soveel as moontlik relevante inligting vir dekodering en produksie daarin wil hê. In e-woordeboeke is dit nie 'n probleem nie omdat slegs die dekoderingsopsie of die produksie-opsie (naas ander potensiële opsies) gekies kan word. Die lemmas wat in 'n standaardwoordeboek opgeneem word, kom hoofsaaklik uit die standaardvariëteit van die betrokke taal (Gouws 2017: 444).

\subsection{Die raamstruktuur}

'n Gedrukte standaardwoordeboek moet sowel 'n sentrale woordelys as minstens 'n voorteks met gebruikersleiding bevat en 'n titelblad en inhoudsopgawe word ook aanbeveel (Ptaszynski 2009: 249). Ptaszynski (2009: 249) argumenteer dat buitetekste (insluitend die titelblad en inhoudsopgawe) funksiebepaald is. Ptaszynski (2009: 249) meld verder dat die funksie van 'n betrokke woordeboek die struktuur en inhoud van hierdie datatipes bepaal, maar nie die opname daarvan nie omdat gesê kan word dat enige woordeboek hierdie buitetekste kan bevat, ongeag die funksie van die woordeboek.

Die inhoudsopgawe kan deur sowel die funksie as die woordeboekmedium beïnvloed word (Ptaszynski 2009: 249-250). 'n Inhoudsopgawe in 'n gedrukte woordeboek kan met ' $n$ keuselys in 'n e-woordeboek vervang word. Fuertes-Olivera en Niňo-Amo (2011: 172) noem dat 'n keuselys wat maklik is om te gebruik, noodsaaklik is omdat die gebruikers data vinnig moet kan opspoor. Met hierdie keuselys beweeg gebruikers tussen datatipes rond (Bothma 2011: 81, 83 en Fuertes-Olivera 2013: 331).

\subsection{Die dataverspreidingstruktuur}

Hierdie struktuur stem gewoonlik ooreen met dié van omvattende woordeboeke.

\subsection{Die makrostruktuur}

Die kriteria vir die opname van lemmas in standaardwoordeboeke is deur, onder andere, Swanepoel (2003: 56), Svensén (2009: 368-378) en Bergenholtz en Tarp (2003: 71-72) aangetoon. Die lemmakeuse moet hoofsaaklik uit die standaardvariëteit van die taal gemaak word (weens ruimtekwessies) tensy dit van belang is vir dekodering (De Caluwé en Van Santen 2003: 72; Gouws 2017: 444). Die gebruiker moet al die data vir dekodering maklik kan opspoor (Bogaards 2003: 29), wat beteken dat die leksikograaf hoofsaaklik 'n streng alfabetiese makrostruktuur met groepering (sublemmas) sal moet gebruik (Svensén 2009: 370-371). Bergenholtz en Gouws (2013: 72) verduidelik dat samestellings veral 
belangrik vir dekodering in 'n standaardwoordeboek is. Indien die gebruiker die werklike betekenis van ' $n$ samestelling wil begryp en slegs die aparte stamme word as lemmas opgeneem, kan die gebruiker ten opsigte van ondeursigtige samestellings ' $n$ begrip-probleem ervaar. Daar moet dus gebruik gemaak word van verklaarde samestellings as hooflemmas, bv. donskoring, skrikkeljaar, skutsluis en vruggebruik.

Sublemmas kan slegs deur ander lemmas bereik word, en indien 'n woordeboek 'n kronkelordening toon as gevolg van die horisontale opname van sublemmas, vorm dit ' $n$ artikelkluster (Gouws 2017: 450). Verder kan nislemmas effektief in standaardwoordeboeke vir begrip gebruik word deur die morfologies verwante woorde op te neem (Gouws 2017: 450-451). 'n Voorbeeld hiervan in die HAT6 is inplons, gevolg deur inplooi op die volgende reël en binne inplooi se artikel kom horisontaal die afleiding inplooiing voor, gevolg deur inplooiwerk op die volgende reël as nuwe lemma.

Neslemmas kom voor waar daar ' $n$ afwyking in die alfabetiese ordeningstruktuur is. Gouws (2017: 450) dui aan dat neslemmas steeds alfabeties in die kluster gehandhaaf kan word, maar dat die daaropvolgende vertikale lemma dan dikwels nie alfabeties georden is nie (eerstevlakse nesting), of dat die alfabetiese ordening in die kluster self kan ontbreek (tweedevlakse nesting). ' $n$ Voorbeeld van eerstevlakse nesting in die HAT6 is die volgende: redeloos, met redenaar op die volgende reël en horisontaal die samestellings redenaars: $\sim$ gawe, $\sim$ kuns, $\sim$ talent, met redenaarskompetisie niealfabeties op die volgende reël. Hierteenoor kom tweedevlakse nesting in die HAT6 voor by hoender, en wel soos volg: hoender op die eerste reël, gevolg deur 'n hele aantal samestellings op horisontale vlak beginnende met $\sim$ hoenderafval en alfabeties tot by hoendersop, gevolg deur die afleiding met verskillende klempatrone, naamlik hoenderagtig, hoenderagtig en hoenderbors op die volgende reël as volgende lemma. Die alfabetiese ordening word tussen hoendersop en hoenderagtig (in die kluster) onderbreek.

\subsection{Die mikrostruktuur}

\subsubsection{Aanduiders en struktuurmerkers}

Vir dekodering is veral semantiese leiding deur middel van betekenisverklarings, woordsoortaanduiding en soms uitspraakleiding, kollokasies en etikette nodig.

Die onderstaande uittreksel vanuit die VivA-webwerf gee die elektroniese resultaat uit die HAT6 vir die lemma kerk, en dien ter illustrasie van nietipografiese struktuurmerkers in die elektroniese weergawe van die HAT6: 


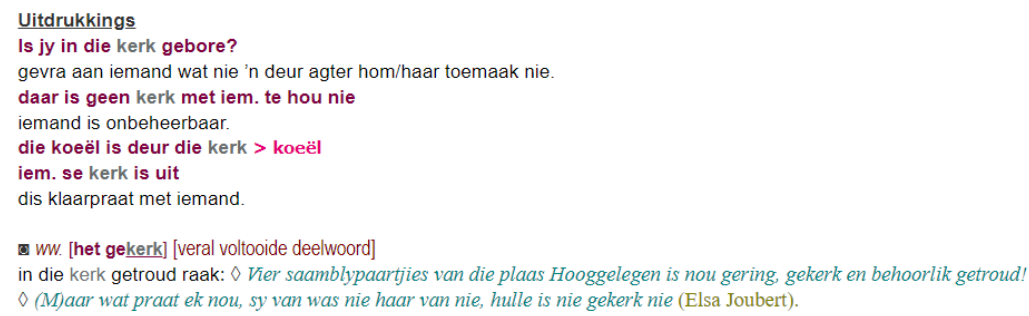

Die blokkie word voor woordsoorte geplaas en die $\diamond$ voor sitate.

Figuur 1: Die nietipografiese struktuurmerkers vanuit Viv A

\subsubsection{Uitspraakleiding}

Daar is gevalle waar uitspraakleiding wel relevant vir dekodering is. Vergelyk byvoorbeeld die betekenisverskil by oorgiet in die VAW waar oorgiet met die klem op oor- beteken "uit een voorwerp in 'n ander gooi" of "weer giet", teenoor oorgiet met die klem op -giet wat "bedek met iets wat uitgegiet word, sprei" beteken.

\subsubsection{Kollokasies}

L'homme en Bertrand (2000: 498) argumenteer dat kollokasies onvoorspelbaar is, wat beteken dat hulle, vir dekodering, in 'n woordeboek, selfs in 'n standaardwoordeboek, opgeneem moet word. Moedertaalsprekers kan ook probleme met kollokasies hê (Braasch en Olsen 2000: 475) en in die HAT6, byvoorbeeld, word kollokasies in 'n artikel duidelik met die simbool | gemerk (sien uittreksel hieronder):

| dubbele standaarde model waarvolgens (...) | enkele standaard standaard met alleen (...) | dubbele standaard standaard waarby sowel (...)

Figuur 2: Die aanduiding van die kollokasies met standaard

\subsubsection{Etikette}

Etikette moet in standaardwoordeboeke vir begrip betrek word, veral by polisemiese items. In die HAT help etikette byvoorbeeld om die verskillende betekenisonderskeidings van papegaaibek van mekaar te onderskei:

pa.pe.gaai.bek s.nw. [ $\sim \mathbf{k e}] \mathbf{1}$ bek van 'n papegaai. $\mathbf{2}$ (veearts.) afwyking by skape, waarby die bokaak oor die onderkaak uitsteek. 3 (tuinb.) groot, sterk soort boomskêr... 4 moersleutel vir pype. 


\subsection{Die toegangstruktuur}

Die toegangstruktuur van standaardwoordeboeke stem ooreen met dié van omvattende woordeboeke. Vergelyk verder Gouws (2017: 449) en Svensén (2009: 441).

\section{Beperkte woordeboeke}

Gouws (2017: 441) sê dat 'n beperkte woordeboek 'n beperktheid het ten opsigte van lemmakeuses wat opgeneem word. 'n Idioom- of sinoniemwoordeboek bevat byvoorbeeld slegs 'n gedeelte van die betrokke taal se leksikon.

\subsection{Die raamstruktuur}

Die raamstruktuur van 'n beperkte woordeboek hang af van die datatipes wat daarin opgeneem word, want die datatipes en hulle bewerking kan, soos Swanepoel (2003: 58) en Gouws (2017: 442) aantoon, ook beperk wees.

\subsection{Die dataverspreidingstruktuur}

Die dataverspreidingstruktuur van ' $n$ beperkte woordeboek is soortgelyk aan dié van 'n woordeboek vir spesiale doeleindes (voortaan WSD) omdat dit ook beperkte datatipes kan bevat.

\subsection{Die makrostruktuur}

Die lemmakeuse sal slegs uit 'n deel van die taal se leksikon bestaan (Swanepoel 2003: 58). In die geval van die gedrukte Idiomewoordeboek (De Villiers en Gouws 1988) word 'n beperkte hoeveelheid lemmas opgeneem. In die elektroniese Afrikaanse idiomewoordeboek kan ' $n$ baie groter getal idiome opgeneem word weens die feit dat 'n elektroniese databasis nie ruimteprobleme sal hê nie. Die gebruikers kan self kies watter lemma en datatipes hulle wil opsoek volgens die funksies wat hulle benodig (Ball 2016: 225).

\subsection{Die mikrostruktuur}

In die geval van Idiomewoordeboek word naas die lemma en trefbegrip wat die idioom in ' $n$ algemene betekenisveld plaas, slegs die idiome, hulle betekenisse en Engelse vertalings verskaf, soos byvoorbeeld in die geval van wans:

wans DADELIK Uit wans uit: Uit die staanspoor. Then and there. On the spot.

Figuur 3: Die mikrostruktuur van Idiomewoordeboek, geilllustreer deur middel van die lemma wans 


\subsection{Die toegangstruktuur}

Die toegangstruktuur vir 'n beperkte woordeboek vir dekodering is soortgelyk aan dié vir 'n WSD vir dekodering.

\section{Aanleerderwoordeboeke}

Aanleerderwoordeboeke kan vir dekodering, produksie en vertaling gebruik word. Die funksie dekodering is dus slegs een van die funksies wat ' $n$ invloed op die struktuur van aanleerderwoordeboeke het.

Tarp (2008: 137) noem twaalf kriteria wat gebruik kan word om die eienskappe van 'n spesifieke tipe aanleerder te probeer identifiseer. Volgens hom is onder meer die aanleerder se algemene kulturele kennis asook hoeveel die aanleerder reeds weet van die betrokke kultuur van die taal wat hy/sy wil aanleer, van belang:

i. Hoe wyd is die aanleerder se algemene kulturele kennis?

ii. Hoe wyd is die aanleerder se kennis van die kultuur in die vreemde taal?

Moon (2016: 138) en Sánchez (2010: 111) argumenteer dat aanleerders sekere kulturele data benodig om byvoorbeeld die konnotasies van 'n woord korrek te verstaan.

\subsection{Die raamstruktuur}

As 'n draer van tekssoorte (Gouws 2017: 457) moet aanleerderwoordeboeke meer as slegs die sentrale teks bevat. Die buitetekste is veral belangrik vir die funksie dekodering, aangesien dit addisionele data wat van 'n algemene of kulturele aard is, kan bevat.

Heuberger (2016: 30) dui aan dat die lemmas en hul betekenisonderskeidings op ' $n$ manier aangebied moet word wat sal verseker dat die aanleerder dit maklik kan verstaan en terselfdertyd hul woordeskat verbreed.

Die voortekste (titelblad, inhoudsopgawe, gebruikersleiding (wat die gebruiksleiding insluit)), middeltekste en agtertekste vorm alles deel van die buitetekste.

Die gebruikersleiding van 'n aanleerderwoordeboek moet so saamgestel word dat dit relevante data vir die teikengebruiker bevat. Volgens Otto (1989: 406) omsluit die noodsaaklike data wat die gebruikersleiding van 'n eentalige aanleerderwoordeboek behoort te bevat, die volgende: die doel van die woordeboek, hoe dit saamgestel is, die omvang daarvan, die datatipes wat voorsien word, data oor die klanksisteem van die taal, 'n minigrammatika, hoe semantiese en gebruiksleiding aangebied word, spellingleiding, lyste wat onreëlmatige vorme bevat, afkortings en SI-eenhede en hulle veelvoude. 


\subsection{Die dataverspreidingstruktuur}

Die dataverspreidingstruktuur is soortgelyk aan dié van die omvattende en standaardwoordeboek, hoewel middel- en/of agtertekste meer benut word (Vergelyk Atkins en Rundell 2008: 177).

\subsection{Die makrostruktuur}

Die spesifieke makrostruktuurelemente wat opgeneem word, behoort op die teikengebruiker se behoeftes gebaseer te wees. Gouws (2017: 452) sê dat die woordeboeksoort en die naslaan- en woordeboekgebruiksvaardighede van die teikengebruikers ' $n$ bepalende rol speel in die vasstelling van die tipe makrostruktuur. Die lemmas moet onder andere ten minste uit die gebruiklikste woordeskat van die betrokke taal geneem word, maar enige ander lemmas wat ook opgeneem word, behoort nie afgeskeep te word wat die bewerking daarvan betref nie (Rundell 2015: 304). Hoe meer leksikale items opgeneem kan word, hoe meer sal daar aan die behoeftes van die aanleerders voldoen word (Bogaards 1996: 281).

Die Macmillan English Dictionary for Advanced Learners (MEDAL) bevat nie slegs gebruiklike woorde wat in rooi aangedui is in die sentrale teks nie, maar verskaf ook ander lemmas buite die kernwoordeskat van die betrokke taal wat die gebruiker dalk nie verstaan nie. Heuberger (2016: 30) sê dat hierdie bykomende woorde veroorsaak dat die gebruikers hulle beter verstaan, wat terselfdertyd ook die gebruiker se woordeskat sal verbreed.

Die polifunksionaliteit van ' $\mathrm{n}$ aanleerderwoordeboek is belangrik ten opsigte van die ordeningstruktuur en moet daar, soos Chi (2013: 168) argumenteer, besluit word of 'n streng alfabetiese makrostruktuur met of sonder groepering gebruik gaan word.

\subsection{Die mikrostruktuur}

\subsubsection{Aanduiders en struktuurmerkers}

Tarp (2008: 77, 149) sê dat gebruikers lemmas, ortografie (variasie en foute), ongereelde fleksievorme, woordsoorte en pragmatiese en kulturele beperkings vir begrip benodig. Die volgende is uittreksels uit die artikel van hoog in Basiswoordeboek van Afrikaans: 
hoog (hoë, hoër, die hoogste) adj. (...) Teenoor: laag (...)

Mense en diere is lank en nie hoog nie. Hoe laag iets ook al is wanneer dit gemeet

word, sê 'n mens byvoorbeeld Dit is $10 \mathrm{~cm}$ hoog, en nie Dit is $10 \mathrm{~cm}$ laag nie.

Benewens betekenisverklarings en uitdrukkings, wat nie in hierdie uittreksel aangedui word nie, word ook die volgende data verskaf: die lemma, verboë vorm van die adjektief, trappe van vergelyking, woordsoortaanduiding, antoniem en 'n gebruikswaarskuwing in 'n teksblokkie.

Figuur 4: Aanduiders in Basiswoordeboek van Afrikaans

\subsubsection{Uitspraakleiding}

Uitspraakleiding is soms noodsaaklik vir begrip. In Basiswoordeboek van Afrikaans, byvoorbeeld, word die klem- en betekenisverskil by volmaak (vul) en volmaak (perfek) aangedui.

\subsubsection{Etimologiese leiding}

Daar kan ook etimologiese leiding in ' $n$ aanleerderwoordeboek vir dekodering wees, wat aandui aan watter taal/tale 'n betrokke woord ontleen is (Otto 1989: 411) en hoekom ' $n$ bepaalde woord uiteindelik 'n bepaalde betekenis gekry het. In hierdie verband verwys Ilson (1983: 77) na die verduideliking van die oorsprong van aboveboard in die Webster's New (8th) Collegiate Dictionary: [Fr. the difficulty of cheating at cards when the hands are above the table], waar die laaste deel uitgebrei kan word om te lees [... the table (the 'board') ].

\subsubsection{Kollokasies}

Kollokasies is wel soms relevant vir begrip, veral waar dit ' $n$ idiomatiese of halfidiomatiese betekenis het, soos by put up, wat byvoorbeeld kan kollokeer met "a (great) fight, (little) resistance, a (spirited) defense" (vergelyk MEDAL: 1150). Kollokasies kan verder gebruik word om verskillende betekenisonderskeidings van óf basisse óf kollokatore van mekaar te onderskei, soos by byvoorbeeld raad vra, ouers vra, aandag vra (Otto 1989: 244). Die basis is hier vra en die betekenis verander by die kollokatore vanaf "versoek" na "ouers se goedkeuring vir 'n huwelik versoek" en uiteindelik "verg".

Kollokasies kan op meer as een plek verskyn. Otto (1989: 299) argumenteer dat in die geval van 'n bekende kollokasie, soos 'n lied sing, dit nie nodig sal wees om die kollokasie ook onder sing op te neem nie, terwyl 'n onbekender kollokasie, soos 'n boom ontwortel, onder boom en ontwortel opgeneem behoort te word. Vergelyk ook Dziemianko (2017: 341) vir probleme met opspoorbaarheid. 


\subsubsection{Etikette}

Etikette moet in 'n aanleerderwoordeboek ingesluit word ter wille van dekodering ten einde betekenisonderskeidings van mekaar te onderskei, byvoorbeeld waar 'n woord sowel 'n algemene as vaktaalbetekenis het. In MEDAL word byvoorbeeld by die eerste lemma van mimic drie betekenisonderskeidings aangedui, waarvan die eerste twee algemene betekenisonderskeidings is, terwyl die derde betekenisonderskeiding geëtiketteer word as science.

\subsubsection{Illustrasies}

Die belangrike rol wat illustrasies in aanleerderwoordeboeke kan speel, word deur Otto (2003: 293-304) bespreek en daar word aangedui dat illustrasies en betekenisverklarings, waar nodig, saam gebruik moet word om te verseker dat belangrike taal- en kulturele aspekte op die duidelikste moontlike manier vir aanleerders verduidelik word.

\subsection{Die toegangstruktuur}

Die toegangstruktuur stem grootliks ooreen met dié van standaardwoordeboeke.

\section{Tweetalige woordeboeke}

Tweetalige woordeboeke het gewoonlik meer as een funksie in gedrukte vorm omdat dit die gebruiker met begrip, produksie en vertaling kan help, en is dus meestal nie uitsluitlik 'n woordeboek vir dekodering nie. Volgens Fontenelle (2016: 45) help tweetalige woordeboeke gebruikers met sowel begrip van die moedertaal as die tweede taal.

\subsection{Die raamstruktuur}

Tweetalige woordeboeke vir dekodering sal 'n soortgelyke raamstruktuur as eentaliges toon.

\subsection{Die dataverspreidingstruktuur}

'n Tweetalige woordeboek vir dekodering se dataverspreidingstruktuur sal op so 'n manier saamgestel moet word dat die teikengebruiker die nodige inligting vir dekodering maklik kan vind, bv. afkortings en volvorme in 'n middelteks. 


\subsection{Die makrostruktuur}

Gouws (2017: 446-447) stel as vereiste vir tweetalige woordeboeke dat die lemmakeuse vertaalekwivalente in die brontaal effektief moet verwerk en opneem, en dat die lemmas uit die standaardvariëteit van die brontaal geneem moet word. Verder moet hierdie lemmas maklik deur die gebruikers gekry en verstaan kan word, soos Kwary (2014: 67) aandui. Tarp (2008: 182) verduidelik dat 'n lemmakeuse wat op frekwensie gebaseer is, nie voldoende vir dekodering sal wees nie omdat gebruikers ' $n$ breër woordeskat nodig sal hê.

\subsection{Die mikrostruktuur}

\subsubsection{Aanduiders en struktuurmerkers}

Tweetalige woordeboeke, juis omdat dit vertaalekwivalente aandui, benodig items wat daardie ekwivalente aandui, soos in die volgende voorbeeld uit Longman-HAT English-Afrikaans / Afrikaans-Engels Basic Dictionary / Basiswoordeboek (LHEABDBW) waar kan as die vertaalekwivalent van might aangegee word:

might modal verb

[USED TO SAY THAT SOMETHING IS POSSIBLE][MAG DALK] $\boldsymbol{k a n}$ Don't eat those berries - they might be poisonous. Moenie daardie bessies eet nie — hulle kan giftig wees. I You might have been killed! Jy kon dood gewees het!

Figuur 5: Uittreksel wat die aanduiders en struktuurmerkers van die LHEABDBW illustreer

Aanduiders kan onder andere uitspraakleiding, grammatiese leiding, morfologie, vertaalekwivalente, etimologiese data of voorbeeldmateriaal insluit. In die voorafgaande uittreksel, byvoorbeeld, kan woordsoortaanduiding, betekenisvertaling, ekwivalente en voorbeeldsinne gesien word, wat relevant vir begrip is.

\subsubsection{Ekwivalensie}

Ekwivalensie is, volgens Adamska-Sałaciak (2013: 222), die absolute verpligte element in enige tweetalige woordeboeke omdat dit lemmas in die brontaal voorsien van vertalings in die teikentaal. Adamska-Sałaciak (2013: 227) sê verder dat ekwivalensie veral belangrik vir dekodering is.

Honselaar (2003: 324) noem dat tweetalige woordeboeke wat passief is (dit wil sê met die fokus op die funksie dekodering), die gebruikers juis toelaat om die teks te verstaan deur een of twee vertaalekwivalente op te neem en dan slegs die minimum bykomende data voorsien. 


\subsubsection{Kollokasies}

Die volgende uittreksel uit die LHEABDBW insake hand dui aan hoe kollokasies, hier by hand, met die hand en hulp verleen, hanteer kan word:

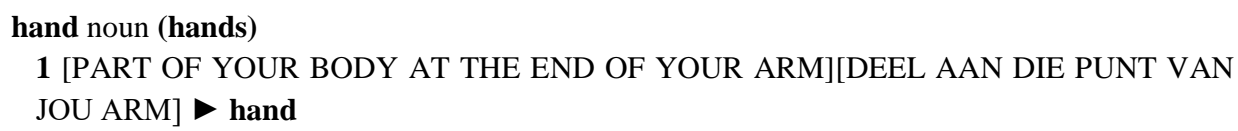

Figuur 6: Uittreksel van die kollokasies uit LHEABDBW

\subsubsection{Uitspraakleiding}

Gevalle waar uitspraakleiding wel tydens dekodering van belang is, is wanneer woorde dieselfde gespel word, maar verskillend uitgespreek word wat die klem betref, en hierdie klemverskil kan lei tot betekenisverskil, soos aangedui in Pharos Afrikaans-Engels / English-Afrikaans Woordeboek / Dictionary (PAEW) by oordryf wat onderskeidelik as drift across/blow over en as exaggerate (...) vertaal word.

\subsubsection{Etimologiese leiding}

Etimologiese leiding kan in 'n tweetalige woordeboek vir begrip opgeneem word, aangesien dit die gebruiker se kennis van 'n betrokke woord kan verbeter. In hierdie verband dui Ilson (1983) en Pierson (1989) die waarde van die studie van etimologiese data in die taalklaskamer aan. Leerders sal natuurlik die gevorderde vaardigheid om etimologiese data in woordeboeke te interpreteer, moet aanleer. Meer spesifiek dui Pierson (1989: 57) op grond van sy persoonlike ondervinding as 'n ESL (English Second Language)-onderwyser in Hong Kong aan hoe die studie van etimologie vir intermediêre/gevorderde aanleerders benut kan word. Leerders wat weet dat cranial van die Griekse woord kranion met die betekenis "kopbeen" kom, kan makliker die betekenisse craniate, craniology, craniometry, craniotome, ensovoorts binne konteks aflei.

\subsubsection{Etikette}

Etikette tree volgens Burkhanov (2003: 105) op as ' $n$ aanduiding van die beperkings op die gebruik van leksikale items wat tyd, plek, situasies en kommunikatiewe omstandighede betref. In PAEW dui die etiket (arch.) voor espousal by die lemma huwelik aan dat die gebruiker nie hierdie vertaalekwivalent in ' $n$ moderne konteks moet gebruik nie. 
Atkins en Rundell (2008: 232) noem dat die opname van etikette ingewikkelder in ' $n$ tweetalige woordeboek is as in 'n eentalige woordeboek omdat die ekwivalente in T1 en T2 gemerk moet word.

\subsubsection{Voorbeeldmateriaal}

Vrbinc en Vrbinc (2016: 298) dui aan dat leksikograwe verskillende faktore in ag neem wanneer besluite oor die opname van voorbeeldmateriaal gemaak word. Die getal voorbeelde wat die leksikograaf benut om die gebruik van die leksikale item of ' $n$ bepaalde betekenisonderskeiding van 'n leksikale item te illustreer, kan nie vooraf bepaal word nie, maar sekere riglyne is tog ter sake:

- die semantiese en grammatiese kompleksiteit van die betrokke leksikale item — hoe komplekser, hoe meer voorbeelde (Toope 1996: 167)

- die mate waarin twee kulture van mekaar verskil (Jacobsen et al. 1991: 2788)

- die funksie van die woordeboek - enkodering vereis meer voorbeelde as dekodering (Kromann et al. 1991: 2772).

Vrbinc en Vrbinc argumenteer dat voorbeelde in tweetalige woordeboeke eintlik albei funksies vervul, aangesien daar gewoonlik nie vier stelle tweetalige woordeboeke is om voorsiening te maak vir twee stelle moedertaalsprekers nie (Jacobsen et al. 1991: 2786). In terme van woordeboeke vir dekodering behoort 'n tweetalige woordeboek voorbeeldmateriaal te bevat wat die gebruikers help om 'n vreemde taal te begryp of 'n teks van 'n vreemde taal na die moedertaal te vertaal.

\subsection{Die toegangstruktuur}

Die eksterne toegangstruktuur se soekroete in 'n tweetalige woordeboek vir dekodering is soortgelyk aan dié van eentalige woordeboeke.

Fuertes-Olivera en Niňo-Amo (2011: 172-173) verduidelik dat een van die belangrikste elemente in 'n elektroniese woordeboek ' $n$ webtuiste met ' $n$ eenvoudige adres is, en dat die soekfunksie maklik gebruik moet kan word.

\section{Woordeboeke vir spesiale doeleindes (WSD)}

WSD's kan een of meer funksies hê, afhangende van die teikengebruiker en die vakgebied waarop die betrokke woordeboek gemik is.

\subsection{Die raamstruktuur}

Die sentrale woordelys moet 'n effektiewe ordeningstruktuur hê, hetsy alfabe- 
ties (met of sonder groepering) of sistematies (Svensén 2009: 21). 'n Alfabetiese ordeningstruktuur kom gewoonlik meer dikwels voor, maar Svensén noem dat 'n sistematiese ordeningstruktuur soms beter vir 'n WSD kan wees omdat die lemmas volgens ' $n$ tema/vakgebied gelys word. Bowker (2003: 158) dui aan dat indien 'n WSD van 'n sistematiese ordeningstruktuur gebruik maak, wat die leksikale items volgens vakgebied en/of die verhoudings wat hulle met mekaar toon lys, kan die items wel alfabeties in die indeks gelys word. Hierdie indeks is dan deel van die buitetekste en kom gewoonlik in die agterteks voor, soos in die onderstaande uittreksel uit A Thesaurus of Medical Words and Phrases uitgebeeld:

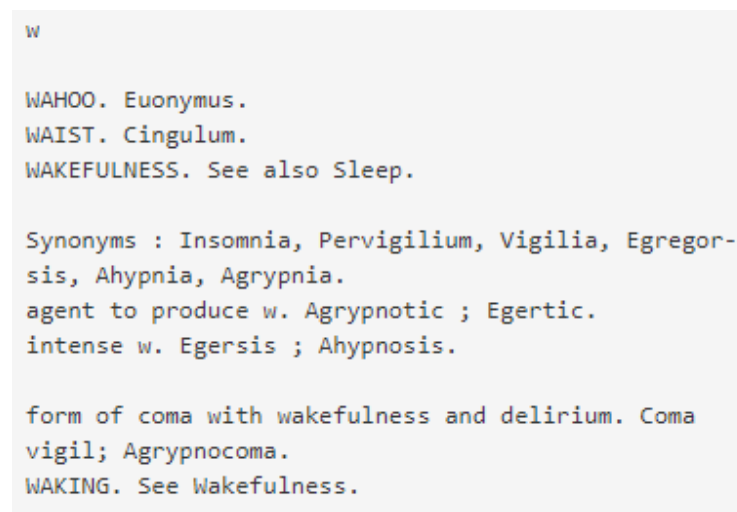

Figuur 7: Die indeks in die agterteks van A Thesaurus of Medical Words and Phrases

Dit is dus eintlik die teikengebruikers en gebruiksituasies wat die ordeningstruktuur van die betrokke WSD bepaal.

\subsection{Die dataverspreidingstruktuur}

WSD's is beperk ten opsigte van hulle datatipes, gevolglik moet die leksikograaf data wat vir dekodering relevant is, in die WSD se sentrale teks plaas, terwyl enige bykomende data in buitetekste kan verskyn.

\subsection{Die makrostruktuur}

WSD's kan alfabeties of sistematies georganiseer word. Die kriteria vir die opname en bewerking van lemmas in 'n WSD vir begrip is soos volg, volgens Bowker (2003: 157-158) en Svensén (2009: 377-378): die lemmas moet slegs opgeneem word as dit relevant vir die vakgebied en teksbegrip is, en die gebruiker moet die data wat vir dekodering opgeneem word maklik kan op- 
spoor, wat beteken dat die leksikograaf 'n alfabetiese indeks moet verskaf as die WSD nie alfabeties georden is nie.

\subsection{Die mikrostruktuur}

Bowker (2003: 159) verduidelik dat hoe meer gespesialiseerd 'n WSD is, hoe minder sal die datatipes wees (soos in die geval van gevorderde gebruikers wat reeds met die betrokke vakgebied en woordeboektipe vertroud is). Betekenisverklaring is wel noodsaaklik.

In hierdie verband behoort betekenisverklaring eiesoortig in verskillende woordeboektipes verklaar te word. Die woord haarskeerder kan byvoorbeeld deur verskillende gebruikers teëgekom word. Indien 'n aanleerder hierdie woord in 'n aanleerderwoordeboek sou naslaan en die betekenisverklaring "groot, harige spinnekop" sou kry, sal dit verstaanbaar wees, maar tegnies verkeerd, aangesien dit ' $n$ unieke insek is en nie ' $n$ spinnekop nie. ' $n$ Moedertaalspreker wat die woord in 'n teks teëkom en ook uit die konteks kan raai dat dit 'n tipe insek is, maar wil weet watter soort insek dit is, kan eweneens mislei word deur die eerste kort betekenisverklaring in byvoorbeeld VAW: 1 Groot, harige en vinnige soort spinnekop, jagspinnekop (Solifuga). 'n Leek wat besig is om ' $n$ boek te lees en net vinnig die betekenis in ' $n$ WSD wil verifieer, sal waarskynlik nie die moeite doen om Solifuga in 'n ander bron te gaan naslaan nie. Buitendien is dit nie gebruikersvriendelik om nog 'n soektog te moet uitvoer as jy net vinnig ' $n$ betekenis wil verifieer nie. In laasgenoemde geval is slegs ' $n$ kort, korrekte verklaring nodig wat aandui dat dit 'n unieke insek is wat lyk soos 'n kruising tussen 'n harige spinnekop en 'n skerpioen as gevolg van groot knypers. Vir 'n semi-deskundige wat 'n teks lees en die woord in 'n WSD naslaan om die betekenis binne die spesifieke konteks te verstaan, is 'n uitvoeriger verklaring nodig, aangesien hierdie persoon oor gespesialiseerde kennis beskik en in fyner besonderhede sal belangstel. Hierdie tipe gebruiker sal waarskynlik wil weet tot watter biologiese familie die insek behoort, of dit giftig is of nie, ensovoorts. Die wetenskaplike naam en ander besonderhede is dus belangrik, byvoorbeeld dat dit niegiftig, baie vinnig is, nie teen glase op kan beweeg nie en baie seer kan byt as dit bedreig word. Vir die ekspert wat 'n WSD raadpleeg, sal feitlik net 'n etiket en die wetenskaplike naam voldoende wees. Vir die leek en semi-deskundige sal 'n etiket in 'n algemene WSD nodig wees om dié term van die algemene woord haarskeerder te onderskei.

\subsubsection{Aanduiders en struktuurmerkers}

Die funksie dekodering het ' $n$ invloed op beide die aanduiders en struktuurmerkers in WSD's. WSD's bevat beperkte datatipes, daarom sal struktuurmerkers die gebruiker help om vinnig by data vir teksbegrip uit te kom. 


\subsubsection{Uitspraakleiding}

Uitspraakleiding is ' $n$ belangrike element van 'n mikrostruktuur, maar omdat WSD's beperkte data bevat, sal hierdie datatipe moontlik nie in alle WSD's voorsien word nie. In die geval van die Farlex Partner Medical Dictionary for Health Consumers, word daar wel uitspraakleiding verskaf, soos in die volgende geval:
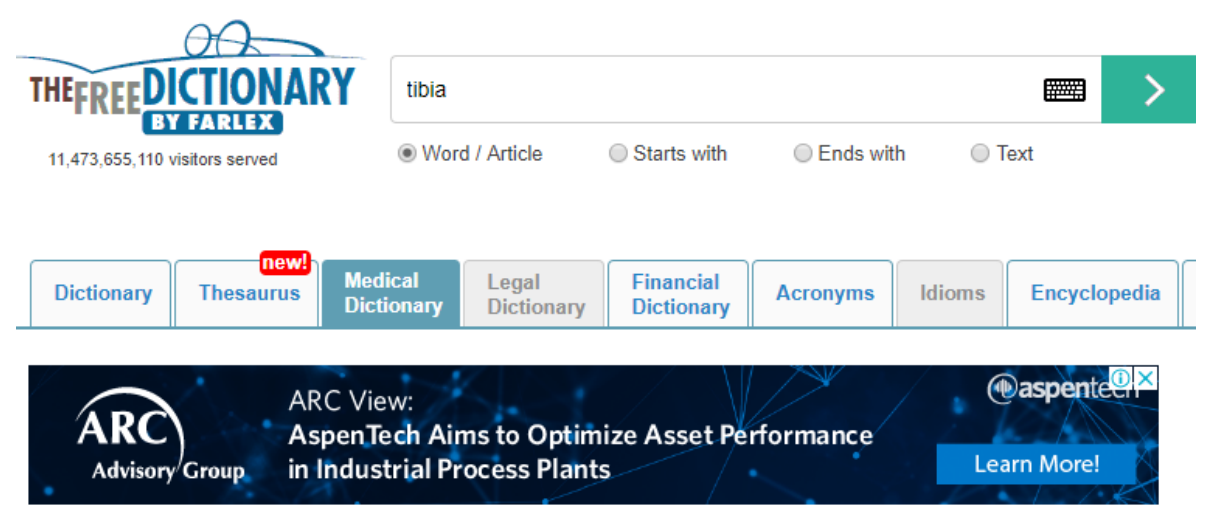

tibia 5

Also found in: Dictionary, Thesaurus, Financial, Acronyms, Encyclopedia, Wikipedia.

tibia [tib'e-ah]

the inner and larger of the two bones of the lower leg; it articulates with the FEMUR and head of the FIBULA above and with the TALus below. See appendix 3-3 and see color plates

Figuur 8: Die uitspraakgids in Farlex Partner Medical Dictionary for Health Consumers

\subsubsection{Etikette}

Indien die WSD meer as een vakgebied behandel en dus nie besonder gespesialiseerd is nie, is die opname van etikette uiters belangrik (Bowker 2003: 159).

\subsubsection{Die toegangstruktuur}

Die eksterne toegangstruktuur se soekroete vir dekodering in 'n WSD sal die omslag, die gebruikersgids en loopkoppe insluit, en intern sal 'n indeks nuttig wees.

\section{Elektroniese woordeboeke}

Dieselfde aanduidertipes (en meer) kan in elektroniese woordeboeke se dekoderingsopsie voorkom, maar die strukture verskil. Die toegangstruktuur is 
anders weens ' $n$ veelvlakkige artikelstruktuur en gewysigde adresseringstruktuur (Gouws 2018: 182). Die hooftoegangstruktuur val ook nie noodwendig saam met die makrostruktuur nie (Gouws 2018:182). Daar is nie 'n raamstruktuur nie, wel 'n uitgebreide dataverspreidingstruktuur, en selfs 'n woordeboekportaalstruktuur en datatrekkingstruktuur (Gouws 2018: 192) is moontlik.

\section{Samevatting}

Die funksie dekodering het 'n invloed op die woordeboekstrukture en datainhoud van woordeboeke. Die strukture in gedrukte woordeboeke verskil van dié in elektroniese woordeboeke, soos in die voorafgaande paragraaf aangedui. In ware elektroniese woordeboeke kan woordeboekgebruikers op die dekoderingsopsie klik, terwyl die gebruiker van 'n gedrukte woordeboek naas die betekenisverklaring ook deur middel van etikette, woordsoortaanduidings, kollokasies en soms uitspraakleiding, etimologiese leiding en voorbeeldmateriaal tot beter begrip kom. In hierdie artikel is veral op gedrukte woordeboeke gefokus. Verdere navorsing behoort op die kriteria vir dekodering in elektroniese woordeboeke te fokus. Die sistematiese beskrywing van die funksies produksie en vertaling word ook in die vooruitsig gestel.

\section{Bronnelys}

\section{A. Elektroniese woordeboeke}

Farlex Partner Medical Dictionary for Health Consumers 2007: https://medical-dictionary.thefreedictionary. com/tibia [2 April 2019].

VivA. Virtuele Instituut vir Afrikaans: www.viva-afrikaans.org.

\section{B. Gedrukte woordeboeke}

Barton, W.M. 1903. A Thesaurus of Medical Words and Phrases. Philadelphia/New York/Londen: W.B. Saunders \& Company.

Botha, W.F. (Hoofred.). 2005. Woordeboek van die Afrikaanse Taal, Deel XII. Stellenbosch: Buro van die WAT.

De Villiers, M. en R.H. Gouws. 1988. Idiomewoordeboek. Kaapstad: Nasou.

Du Plessis, M. 2005. Pharos Afrikaans-Engels / English-Afrikaans Woordeboek / Dictionary. Kaapstad: Pharos.

Gouws, R., I. Feinauer en F. Ponelis. 1994. Basiswoordeboek van Afrikaans. Pretoria: Van Schaik.

Labuschagne, F.J. en L.C. Eksteen. 2010. Verklarende Afrikaanse Woordeboek. Negende, hersiene uitgawe. Kaapstad: Pharos.

Luther, J. (Red.). 2011. Longman-HAT English-Afrikaans / Afrikaans-Engels Basic Dictionary / Basiswoordeboek. Pietermaritzburg: Pearson. 
Luther, J., F. Pheiffer en R.H. Gouws (Reds.). 20156. HAT Verklarende Handwoordeboek van die Afrikaanse Taal. Kaapstad: Pearson.

Morris, W. 1985. The American Heritage Dictionary. Boston: Houghton Mifflin.

Rundell, M. en G. Fox (Hoofreds.). 2002. Macmillan English Dictionary for Advanced Learners. Oxford: Macmillan Education.

Van Schalkwyk, D.J. (Hoofred.). 1996. Woordeboek van die Afrikaanse Taal, Deel X. Stellenbosch: Buro van die WAT.

Van Schalkwyk, D.J. (Hoofred.). 1996. Woordeboek van die Afrikaanse Taal, Deel XI. Stellenbosch: Buro van die WAT.

\section{Ander bronne}

Adamska-Sałaciak, A. 2013. Issues in Compiling Bilingual Dictionaries. Jackson, H. (Red.). 2013: 213-231.

Atkins, B.T.S. en M. Rundell. 2008. The Oxford Guide to Practical Lexicography. Oxford/New York: Oxford University Press.

Ball, L. 2016. An Evaluative Study to Determine to What Extent Technology Can be Used in e-Dictionaries to Provide Relevant Information on Demand. Ongepubliseerde M.A.-verhandeling. Pretoria: Universiteit Pretoria.

Béjoint, H. 2016. Dictionaries for General Users: History and Development; Current Issues. Durkin, P. (Red.). 2016: 7-24.

Bentivogli, L. en E. Pianta. 2002. Detecting Hidden Multiwords in Bilingual Dictionaries. Braasch, A. en C. Povlsen (Reds.). 2002: 785-793.

Bergenholtz, H. en R.H. Gouws. 2013. The Presentation of Word Formation in General Monolingual Dictionaries. Lexikos 23: 59-76.

Bergenholtz, H. en S. Tarp. 2003. Two Opposing Theories: On H.E. Wiegand's Recent Discovery of Lexicographic Functions. Hermes, Journal of Linguistics 31: 171-196.

Blume, J. 2017. ' $n$ Ondersoek na die kriteria vir die realisering van die woordeboekfunksies begrip, produksie en vertaling. Ongepubliseerde M.A.-verhandeling. Port Elizabeth: Nelson Mandela Universiteit.

Bogaards, P. 1996. Dictionaries for Learners of English. International Journal of Lexicography 9(4): 277-320.

Bogaaards, P. 2003. Uses and Users of Dictionaries. Van Sterkenburg, P. (Red.). 2003: 26-33.

Bogaards, P. 2013. A History of Research in Lexicography. Jackson, H. (Red.). 2013: 19-32.

Botha, W. (Red.). 2003. ' $n$ Man wat beur: Huldigingsbundel vir Dirk van Schalkwyk. Stellenbosch: Buro van die WAT.

Botha, W., P. Mavoungou en D. Nkomo (Reds.). 2013. Festschrift Rufus H. Gouws. Stellenbosch: SUN PReSS.

Bothma, T.J.D. 2011. Filtering and Adapting Data and Information in the Online Environment in Response to User Needs. Fuertes-Olivera, P.A. en H. Bergenholtz (Reds.). 2011: 71-102.

Bowker, L. 2003. Specialized Lexicography and Specialized Dictionaries. Van Sterkenburg, P. (Red.). 2003: 154-164.

Braasch, A. en S. Olsen. 2000. Formalised Representation of Collocations in a Danish Computational Lexicon. Heid, U. et al. 2000: 475-488.

Braasch, A. en C. Povlsen (Reds.). 2002. Proceedings of the Tenth EURALEX International Congress, EURALEX 2002, Copenhagen, Denmark, August 13-17, 2002. Kopenhagen: Center for Sprogteknologi. 
Brinker, K. et al. (Reds.). 2000. Text und Gesprächslinguistik. HSK 16(1). Berlyn/New York: De Gruyter.

Burkhanov, I. 2003. Pragmatic Specifications: Usage Indications, Labels, Examples; Dictionaries of Style, Dictionaries of Collocations. Van Sterkenburg, P. (Red.). 2003: 102-113.

Carstens, W.A.M. en N. Bosman (Reds.). 2017. Kontemporêre Afrikaanse Taalkunde. Tweede uitgawe. Pretoria: Van Schaik.

Chi, A. 2013. Researching Pedagogical Lexicography. Jackson, J. (Red.). 2013: 165-187.

Cowie, A. (Red.). 1987. The Dictionary and the Language Learner. Papers from the EURALEX Seminar at the University of Leeds, 1-3 April 1985. Tübingen: Max Niemeyer.

Cowie, A. (Red.). 1998. Phraseology: Theory, Analysis, and Applications. Oxford: Clarendon Press.

De Caluwé, J. en A. van Santen. 2003. Phonological, Morphological and Syntactic Specifications in Monolingual Dictionaries. Van Sterkenburg, P. (Red.). 2003: 71-82.

Du Plessis, A.H. 2017. Die rol van die bruikbaarheidsbenadering binne die e-leksikografie. Literator 38(2). https://doi.org/10.4102/lit. v38i2.1340.

Durkin, P. (Red.). 2016. The Oxford Handbook of Lexicography. New York: Oxford University Press.

Dziemianko, A. 2017. Dictionary Form in Decoding, Encoding and Retention: Further Insights. ReCALL 29(3): 335-356.

Fontenelle, T. 2016. Bilingual Dictionaries: History and Development; Current Issues. Durkin, P. (Red.). 2016: 44-61.

Fuertes-Olivera, P.A. (Red.). 2010. Specialised Dictionaries for Learners. Berlyn/New York: De Gruyter.

Fuertes-Olivera, P.A. 2013. E-lexicography: The Continuing Challenge of Applying New Technology to Dictionary-Making. Jackson, H. (Red.). 2013: 323-340.

Fuertes-Olivera, P.A. en H. Bergenholtz (Reds.). 2011. e-Lexicography: The Internet, Digital Initiatives and Lexicograpy. Londen/New York: Continuum.

Fuertes-Olivera, P.A. en M. Niňo-Amo. 2011. Internet Dictionaries for Communicative and Cognitive Functions: El Diccionario Inglés-Espaňol de Contabilidad. Fuertes-Olivera, P.A. en H. Bergenholtz (Reds.). 2011: 168-186.

Gouws, R.H. 1988. Die gebruik van etikette as leksikografiese hulpmiddel. Suid-Afrikaanse Tydskrif vir Taalkunde, Geleentheidsuitgawe 6, April 1988: 1-56.

Gouws, R.H. 1989. Leksikografie. Pretoria/Kaapstad: Academica.

Gouws, R.H. 2003. Types of Articles, their Structure and Different Types of Lemmata. Van Sterkenburg, P. (Red.). 2003: 34-43.

Gouws, R.H. 2017. Leksikografie. Carstens, W.A.M. en N. Bosman (Reds.). 2017: 429-461.

Gouws, R.H. 2018. 'n Leksikografiese datatrekkingstruktuur vir aanlyn woordeboeke. Lexikos 28: 177-195. http://Lexikos.journals.ac.za; https://doi.org/10.5788/28-1-1461.

Hausmann, F.J. et al. (Reds.). 1989-1991. Wörterbücher. Ein internationales Handbuch zur Lexikographie / Dictionaries. An International Encyclopedia of Lexicography / Dictionnaires. Encyclopédie internationale de lexicographie. Berlyn: De Gruyter.

Heid, U. et al. (Reds.). 2000. Proceedings of the Ninth EURALEX International Congress, EURALEX 2000, Stuttgart, Germany, August 8th-12th, 2000. Stuttgart: Institut für Maschinelle Sprachverarbeitung, Universität Stuttgart.

Heuberger, R. 2016. Learners' Dictionaries: History and Development; Current Issues. Durkin, P. (Red.). 2016: 25-43.

Honselaar, W. 2003. Examples of Design and Production Criteria for Bilingual Dictionaries. Van Sterkenburg, P. (Red.). 2003: 323-332. 
Howarth, P. 1998. The Phraseology of Learners' Academic Writing. Cowie, A.P. (Red.). 1998: 161-188.

Ilson, R. 1983. Etymological Information: Can it Help our Students? ELT Journal 37(1): 76-82.

Ilson, R. 1987. Illustrations in Dictionaries. Cowie, A. (Red.). 1987: 193-211.

Jackson, H. (Red.). 2013. The Bloomsbury Companion to Lexicography. Londen/Nieu-Delhi/New York/Sydney: Bloomsbury Academic.

Jacobsen, J.R, J. Manley en V.H. Pedersen. 1991. Examples in the Bilingual Dictionary. Hausmann, F.J. et al. (Reds.). 1991: 2782-2789.

Kemmer, K. 2010. Onlinewörterbücher in der Wörterbuchkritik: Ein Evaluationsraster mit 39 Beurteilungskriterien. Online publizierte Arbeiten zur Linguistik (OPAL) 2. Mannheim: Institut für Deutsche Sprache.

Klosa, A. (Red.). 2008. Lexikographische Portale im Internet. Online publizierte Arbeiten zur Linguistik (OPAL) 1. Mannheim: Institut für Deutsche Sprache.

Klosa, A. 2016. Illustrations in Dictionaries; Encyclopaedic and Cultural Information in Dictionaries. Durkin, P. (Red.). 2016: 515-531.

Klosa, A., L. Lemnitzer en G. Neumann. 2008. Wörterbuchportale — Fragen der Benutzerführung. Klosa, A. (Red.). 2008: 5-35.

Kromann, H.-P., T. Riiber en P. Rosbach. 1991. Grammatical Constructions in the Bilingual Dictionary. Hausmann, F.J. et al. (Reds.). 1991: 2770-2775.

Kwary, D.A. 2014. The Evolution of Dictionaries of Economics: From a Glossary to a Lexicographical Information System. Hermes: Journal of Language and Communication in Business 27(52): 59-73.

L'homme, M.-C. en C. Bertrand. 2000. Specialized Lexical Combinations: Should they Be Described as Collocations or in Terms of Selectional Restrictions? Heid, U. et al. 2000: 497-506.

Moon, R. 2016. Explaining Meaning in Learners' Dictionaries. Durkin, P. (Red.). 2016: 123-143.

Oppentocht, L. en R. Schutz. 2003. Developments in Electronic Dictionary Design. Van Sterkenburg, P. (Red.). 2003: 215-227.

Otto, A.N. 1989. Kriteria vir 'n Afrikaanse aanleerderwoordeboek. Ongepubliseerde D.Litt.-proefskrif. Stellenbosch: Universiteit Stellenbosch.

Otto, A.N. 2003. Woordeboekillustrasies, met spesiale verwysing na illustrasies in aanleerderwoordeboeke. Botha, W. (Red.). 2003: 293-304.

Otto, A.N. 2013. 'n Kritiese waardering van die hantering van kollokasies en idiome in die HAT (2005). Botha, W. et al. (Reds.). 2013: 188-195.

Pierson, Herbert D. 1989. Using Etymology in the Classroom. ELT Journal 43(1): 57-63.

Ptaszynski, M.O. 2009. Function-related Secondary User Needs and Secondary Data? A Critical Examination of Some Central Concepts in the Modern Theory of Lexicographical Functions. Lexikos 19: 242-261.

Rundell, M. 2015. From Print to Digital: Implications for Dictionary Policy and Lexicographic Conventions. Lexikos 25: 301-322.

Sager, S.F. 2000. Hypertext und Hypermedia. Brinker, K. et al. (Reds.). 2000: 587-603.

Sánchez, A. 2010. The Treatment of Cultural and/or Encyclopaedic Items in Specialised Dictionaries for Learners. Fuertes-Olivera, P.A. (Red.). 2010: 107-129.

Svensén, B. 2009. A Handbook of Lexicography: The Theory and Practice of Dictionary-Making. Cambridge: Cambridge University Press.

Swanepoel, P. 2003. Dictionary Typologies: A Pragmatic Approach. Van Sterkenburg, P. (Red.). 2003: 44-70. 
Tarp, S. 2008. Lexicography in the Borderland between Knowledge and Non-knowledge: General Lexicographical Theory with Particular Focus on Learner's Lexicography. Tübingen: Max Niemeyer.

Toope, M. 1996. Examples in the Bilingual Dictionary. Ongepubliseerde M.A.-verhandeling. Ottawa: Universiteit van Ottawa. [Aanlyn]. Beskikbaar by: http://www.ruor.uottawa.ca/bitstream/ 10393/9942/1/mm15769.PDF.

Van Sterkenburg, P. (Red.). 2003. A Practical Guide to Lexicography. Volume 6. Amsterdam/Philadelphia: John Benjamins.

Vrbinc, A. en M. Vrbinc. 2016. Illustrative Examples in a Bilingual Decoding Dictionary: An (Un)necessary Component? Lexikos 26: 296-310. 